\title{
Microcrustacea (Crustacea: Branchiopoda) of Deepor Beel, Assam, India: richness, abundance and ecology
}

\section{B.K. Sharma ${ }^{1} \&$ Sumita Sharma ${ }^{2}$}

\author{
${ }^{1}$ Department of Zoology, North-Eastern Hill University, Permanent Campus, Umshing, Shillong, Meghalaya 793022, India \\ ${ }^{2}$ Eastern Regional Station, Zoological Survey of India, Fruit Gardens, Risa Colony, Shillong, Meghalaya 793003, India \\ Email: ${ }^{1}$ bksharma@ @ehu.ac.in; ${ }^{2}$ sumitazsi@ hotmail.com
}

\begin{abstract}
Plankton samples collected from two sampling stations of Deepor Beel, an important floodplain lake of Assam and a Ramsar site of India, revealed 51 species of Microcrustacea and showed qualitative dominance of Cladocera (45 species). Microcrustacea comprised a significant quantitative component $(45.6 \pm 5.8$ and $50.8 \pm 4.5 \%)$ of zooplankton and exhibited bimodal and trimodal annual patterns with peaks during winter. Cladocera > Copepoda are important quantitative groups. ANOVA registered significant variation in species richness and abundance of Microcrustacea over time and between stations. Richness and abundance were inversely correlated with water temperature and rainfall, and positively correlated with specific conductivity and dissolved oxygen. Multiple regression registered significantly higher cumulative effects of ten abiotic factors on these two parameters. Our results are characterized by higher species diversity, higher evenness and lower dominance of Microcrustacea and show lack of distinct quantitative importance of individual species.
\end{abstract}

Keywords: Abundance, Deepor Beel, ecology, Microcrustacea, Ramsar site, richness.

Date of publication (online): 26 August 2009 Date of publication (print): 26 August 2009 ISSN $0974-7907$ (online) | 0974-7893 (print)

Editor: R. Jindal

\section{Manuscript details:}

Ms \# 02169

Received 31 March 2009

Final received 02 July 2009

Finally accepted 28 July 2009

Citation: Sharma, B.K. \& S. Sharma (2009). Microcrustacea (Crustacea: Branchiopoda) of Deepor Beel, Assam, India: richness, abundance and ecology. Journal of Threatened Taxa 1(8): 411-418.

Copyright: () B.K. Sharma \& Sumita Sharma 2009. Creative Commons Attribution 3.0 Unported License. JoTT allows unrestricted use of this article in any medium for non-profit purposes, reproduction and distribution by providing adequate credit to the authors and the source of publication.

Author Details: Both the authors specialize in Biodiversity and Ecology of Freshwater Zooplankton and have made significant contributions in the fields of their expertise.

Author Contribution: The present study is the result of collaborative work undertaken by the authors, mainly at the research laboratory of the senior author.

Acknowledgements: This study is undertaken partly under the "Potential for Excellence Program (Focused Area: Biosciences)" of North-Eastern Hill University, Shillong. The authors are thankful to G.B. Pant Institute of Himalayan Environmental Development, Almora for a research grant during which this study was initiated. Thanks are due to the Head, Department of Zoology, North-Eastern Hill University, Shillong for necessary laboratory facilities. One of the authors (SS) is also thankful to the Director, Zoological Survey of India, Kolkata and the Officer-in-Charge, Eastern regional Station, Shillong.

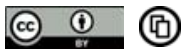

OPEN ACCESS | FREE DOWNLOAD

\section{INTRODUCTION}

Littoral and limnetic habitats of various freshwater ecosystems are colonized by Microcrustacea, which include different groups of brachiopod crustaceans and are also collectively termed 'Entomostraceous Crustacea'. They invariably form an important component of metazooplankton, comprise an integral link of aquatic food-webs, serve as valuable fish-food organisms and contribute notably to secondary productivity in freshwater environments. Microcrustacea are often included in routine limnological studies undertaken from different parts of this country, yet a review of the published literature provides limited information on their ecology, ecosystem diversity and role in aquatic productivity in aquatic ecosystems because of inadequate analysis of their communities, invariably coupled with lack of species determination resulting in incomplete species inventories or inclusion of anomalous reports of taxa warranting conformations. These generalizations hold valid for the diversity of these microinvertebrates in the Indian floodplain lakes in particular (Sharma \& Sharma 2008). The related contributions from the floodplains of northeastern India are so far limited to the works of Sharma \& Hussain (2001) and Sharma \& Sharma (2008).

The present study on Microcrustacea of Deepor Beel, an important floodplain lake of the Brahmaputra River basin of Assam and a Ramsar site of India, assumes special limnological importance in view of the stated lacunae. Observations are made on richness, community similarities, abundance, species diversity, evenness and dominance of Microcrustacea and their constituent groups during one year of the study period. In addition, the influence of abiotic parameters on their richness and abundance are analyzed.

\section{Materials and Methods}

The present study is a part of limnological investigations undertaken during November, 2002 - October, 2003, in Deepor Beel $\left(91^{\circ} 35^{\prime}-91^{\circ} 43^{\prime} \mathrm{E} \& 26^{\circ} 05^{\prime}-26^{\circ} 11^{\prime} \mathrm{N}\right.$, area $40 \mathrm{~km}^{2}$, altitude $42 \mathrm{~m}$ ) located in the Kamrup District of lower Assam (northeastern India). This floodplain lake is covered with luxuriant growth of various aquatic macrophytes namely Hydrilla verticellata, Eichhornia crassipes, Vallisnaria spiralis, Utricularia flexuosa, Trapa bispinosa, Euryale ferox, Najas indica, Monochoria hastaefolia, Xanthium straumarium, Ipomea fistulosa, Hygrorhyza aristata, Polygonum hydropiper and Limnophila sp.

Water samples were collected monthly from two sampling stations (I and II) and were analyzed for various abiotic factors. Water temperature, specific conductivity and $\mathrm{pH}$ were recorded by field probes, transparency was noted with Secchi disc, dissolved oxygen was estimated by modified Winkler's methods and other parameters were analyzed following APHA (1992). Qualitative (by towing) and quantitative plankton (by filtering 251 water each) samples were collected monthly from two stations with 
nylobolt plankton net (No. 25) and were preserved in 5\% formalin. The former were screened and different species were identified following the works of Smirnov (1971, 1976, 1992, 1996), Michael \& Sharma (1988), Korovchinsky (1992), Sharma \& Sharma $(1999,2008)$ and Orlova-Bienkowskaja (2001). Quantitative samples were analyzed for abundance of Microcrustacea and their constituent groups.

Community similarities (Sorensen's index), species diversity (Shannon's index), dominance (Berger-Parker's index) and evenness (E1 index) were calculated following Ludwig \& Reynolds (1988) and Magurran (1988). ANOVA (two-way) was used to analyse significance of temporal variations of the biotic communities. Simple correlation coefficients $\left(r_{1}\right.$ and $\left.r_{2}\right)$ were calculated between abiotic and biotic parameters while multiple regressions $\left(\mathrm{R}^{2}{ }_{1}\right.$ and $\left.\mathrm{R}_{2}{ }_{2}\right)$ were computed with 10 abiotic factors i.e., water temperature, rainfall, $\mathrm{pH}$, transparency, specific conductivity, dissolved oxygen, alkalinity, hardness, phosphate and nitrate for two sampling stations respectively.

\section{Results and Discussion}

Water samples analyzed from Deepor Beel are characterized (Table 1) by low ionic concentrations and thus warrant inclusion of this Ramsar site under 'Class I' category vide Talling \& Talling (1965). Mean water temperature affirms tropical range concurrent with its geographical location. The circum-neutral and marginally hard waters of this floodplain lake record moderate dissolved oxygen, low free $\mathrm{CO}_{2}$ and low concentration of micro-nutrients (Sharma \& Sharma 2008). Chloride and $\mathrm{BOD}_{5}$ values suggest some possible impact of human activity in this wetland.

Fifty-one species of Microcrustacea recorded presently from Deepor Beel (Table 2) reveal highly diverse and speciose biocoenosis of these branchiopod crustaceans and represent their richest diversity so far known from any individual floodplain lake or any freshwater ecosystem of India. These salient features reflect greater environmental heterogeneity of this Ramsar site. Cladocera (45 species) form main qualitative component; an account of taxonomic diversity of this group is dealt with separately by Sharma \& Sharma (2008). In addition, Copepoda, Ostracoda and Conchostraca are represented by three, two and one species respectively.

All the examined species of Microcrustacea occur at station I while 48 species are observed at station II (Table 2). Their monthly richness varies between $34 \pm 6$ (station I) and $38 \pm 6$ species (station II) and registers significant temporal variations between months $\left(\mathrm{F}_{11,23}=14.650, \mathrm{P}<0.005\right)$ as well as stations $\left(\mathrm{F}_{1,23}=15.010, \mathrm{P}<0.001\right)$. Richness follows multimodal and bimodal annual patterns (Figs. 1 \& 2); it shows peaks during winter (February at station I, December and January at station II), minima during summer (April) at both stations while relatively higher richness is noticed during NovemberFebruary. The last feature is affirmed by significant negative correlation with water temperature $\left(r_{1}=-0.624, r_{2}=-0.815\right)$. Microcrustacea richness is also negatively correlated with rainfall $\left(r_{1}=-0.682, r_{2}=-0.700\right)$ and it is positively correlated with specific conductivity $\left(r_{1}=0.567, r_{2}=0.647\right)$ and dissolved oxygen $\left(r_{1}=0.583, r_{2}=0.729\right)$ at both stations and with transparency $\left(r_{2}=0.635\right)$, alkalinity $\left(r_{2}=0.563\right)$ and hardness $\left(r_{2}=0.626\right)$ at station II. Multiple regression indicates significantly higher cumulative effect of ten abiotic factors on richness of Microcrustacea $\left(\mathrm{R}_{1}{ }_{1}=0.971\right.$ and $\left.\mathrm{R}_{2}{ }_{2}=0.987\right)$ at

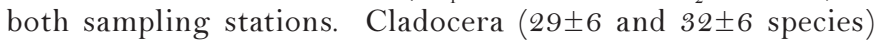
mainly influence qualitative variations (Figs. 1 and 2) of the microcrustaceans $\left(r_{1}=0.992, r_{2}=0.995\right)$.

Our results indicate higher community similarities (vide Sorenson's index) of Microcrustacea (62.3-93.0 and 63.9-98.9\%) with values ranging between $80-90 \%$ in 47.9 and $59.1 \%$ instances in similarity matrices at two sampling stations respectively (Tables $3 \& 4$ ). In general, greater affinities in species composition (Figs. 3 \& 4 ) are noticed during NovemberFebruary and peak similarities are observed between winter communities i.e., December-February (station I) and JanuaryFebruary (station II). On the other hand, the samples collected during March and April indicate greater divergence in their composition at stations I and II respectively (Figs. 3 \& 4).

Microcrustacea (216 553 and $229 \pm 48 \mathrm{n} / \mathrm{l}$ ) form an

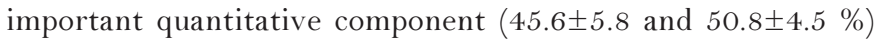
of zooplankton at both sampling stations (Table 2 ) and notably influence temporal variations of the latter $\left(r_{1}=0.901, r_{2}=\right.$ 0.963). They register significant density variations between months $\left(\mathrm{F}_{11,23}=18.915, \mathrm{P}<0.005\right)$ and stations $\left(\mathrm{F}_{1,2 \mathrm{~s}}=3.373\right.$, $\mathrm{P}>0.05)$. Their abundance follows bimodal and trimodal annual patterns (Fig. 5 \& 6), shows peaks during winter (December) at both stations and indicates minima during March and April at stations I and II respectively. Microcrustacea abundance records significant negative correlations with water temperature $\left(r_{1}=-0.714, r_{2}=-0.798\right)$ and rainfall $\left(r_{1}=-0.719\right.$, $\left.r_{2}=-0.679\right)$ and it is positively correlated with transparency $\left(r_{1}\right.$ $\left.=0.483, r_{2}=0.549\right)$, specific conductivity $\left(r_{1}=0.484, r_{2}=0.592\right)$ and dissolved oxygen $\left(r_{1}=0.706, r_{2}=0.681\right)$ at both stations and, with hardness $\left(r_{2}=0.500\right)$ at station II. Multiple regression indicates significantly higher cumulative effect of ten abiotic factors on their abundance $\left(\mathrm{R}^{2}{ }_{1}=0.898 ; \mathrm{R}_{2}^{2}=0.998\right)$ at both sampling stations.

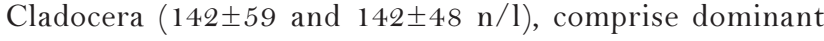
quantitative group (Table 2 ) of the microcrustaceans $(63.0 \pm 13.6$ and $60.6 \pm 9.1 \%)$ and distinctly influence their temporal variations $\left(r_{1}=0.948, r_{2}=0.966\right)$. They also form an important constituent $(28.7 \pm 7.0 \%$ and $30.6 \pm 4.9 \%)$ of zooplankton and notably influence their density variations $\left(r_{1}\right.$ $=0.902, r_{2}=0.903$ ) during the study period. Cladocera abundance follows (Figs. $5 \& 6$ ) trimodal and bimodal annual

Table 1. Temporal variations of abiotic factors

\begin{tabular}{lll}
\hline Factors & Station I & Station II \\
\hline Rainfall $(\mathrm{mm})$ & $204.5 \pm 160.4$ & $204.5 \pm 160.4$ \\
Water temperature $\left({ }^{\circ} \mathrm{C}\right)$ & $27.2 \pm 4.6$ & $27.4 \pm 5.1$ \\
pH & $6.89 \pm 0.18$ & $6.93 \pm 0.21$ \\
Transparency $(\mathrm{cm})$ & $51.9 \pm 26.2$ & $52.7 \pm 25.3$ \\
Specific Conductivity $(\mu \mathrm{S} / \mathrm{cm})$ & $99.2 \pm 13.2$ & $96.8 \pm 15.5$ \\
Dissolved oxygen $(\mathrm{mg} / \mathrm{l})$ & $6.7 \pm 1.6$ & $7.0 \pm 1.1$ \\
Free CO $(\mathrm{mg} / \mathrm{l})$ & $7.2 \pm 2.1$ & $6.8 \pm 1.9$ \\
Alkalinity $(\mathrm{mg} / \mathrm{l})$ & $66.3 \pm 12.1$ & $68.9 \pm 10.3$ \\
Hardness $(\mathrm{mg} / \mathrm{l})$ & $62.1 \pm 9.9$ & $61.2 \pm 12.3$ \\
Calcium $(\mathrm{mg} / \mathrm{l})$ & $20.1 \pm 2.2$ & $22.1 \pm 1.8$ \\
Magnesium $(\mathrm{mg} / \mathrm{l})$ & $4.0 \pm 0.7$ & $4.2 \pm 0.9$ \\
Chloride $(\mathrm{mg} / \mathrm{l})$ & $34.6 \pm 5.2$ & $35.1 \pm 5.0$ \\
Phosphate $(\mathrm{mg} / \mathrm{l})$ & $0.18 \pm 0.07$ & $0.19 \pm 0.10$ \\
Sulphate $(\mathrm{mg} / \mathrm{l})$ & $10.2 \pm 3.2$ & $9.9 \pm 3.4$ \\
Nitrate $(\mathrm{mg} / \mathrm{l})$ & $0.72 \pm 0.12$ & $0.74 \pm 0.14$ \\
B.O.D $(\mathrm{mg} / \mathrm{l})$ & $3.11 \pm 0.59$ & $3.21 \pm 0.46$ \\
Dissolved Organic Matter $(\mathrm{mg} / \mathrm{l})$ & $3.84 \pm 0.80$ & $3.90 \pm 0.64$ \\
Total dissolved Solids $(\mathrm{mg} / \mathrm{l})$ & $2.37 \pm 0.29$ & $2.57 \pm 0.30$ \\
\hline
\end{tabular}



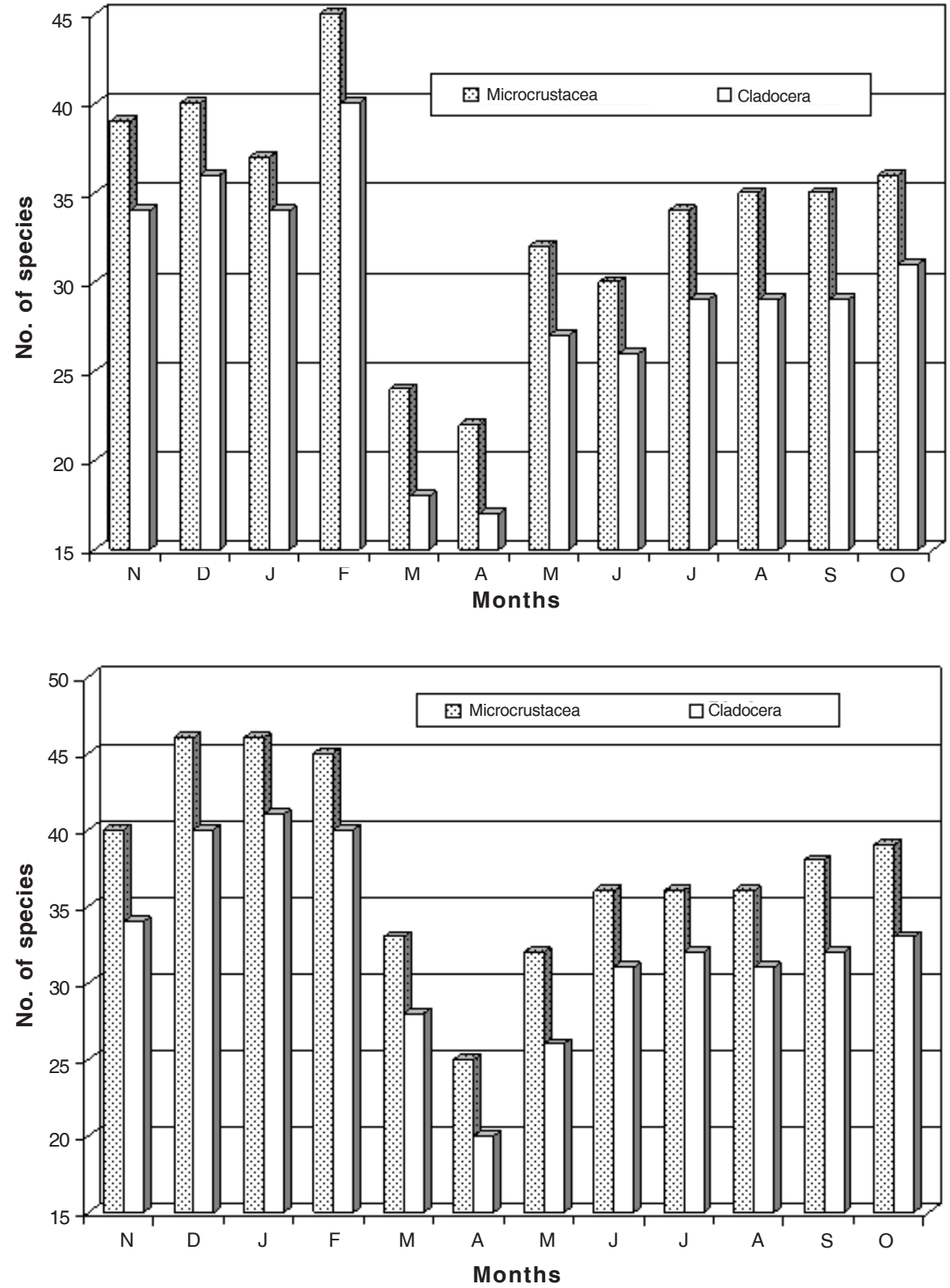

Figure 1. Monthly variations in Microcrustacea and Cladocera richness (Station I)

Figure 2. Monthly variations in Microcrustacea and Cladocera richness (Station II) patterns at two sampling stations respectively, indicate peaks during winter (January and December) and minima during April (summer) each. They register significant density variations between months $\left(\mathrm{F}_{11,23}=27.160, \mathrm{P}<0.005\right)$ and insignificant between stations. The cladoceran abundance is higher than the reports of Khan (1987), Baruah et al. (1993), Sinha et al. (1994), Sharma \& Hussain (2001) and Sharma \& Sharma (2008). In addition, their winter peaks concur with the observations in Loktak Lake (Sharma unpublished) but differ from summer maxima reported by Sanjer \& Sharma (1995) and Sharma and Hussain (2001) while comparisons with other studies in the Indian floodplains are not possible because of lack of definite information. Cladocera abundance is negatively correlated with water temperature $\left(r_{1}=-0.776, r_{2}=-0.803\right)$ and rainfall $\left(r_{1}=-0.768, r_{2}=-0.720\right)$ and it is positively correlated with transparency $\left(r_{1}=0.591, r_{2}=0.609\right)$, dissolved oxygen $\left(r_{1}\right.$ $\left.=0.762, r_{2}=0.683\right)$ and hardness $\left(r_{1}=0.552, r_{2}=0.525\right)$ at both stations and with specific conductivity $\left(r_{2}=0.622\right)$ at station II. Multiple regression indicates significantly higher cumulative effect of 10 abiotic factors on their abundance $\left(\mathrm{R}^{2}{ }_{1}\right.$ $\left.=0.893 ; \mathrm{R}_{2}{ }_{2}=0.993\right)$ at both sampling stations.

Our results exhibit quantitative predominance of the littoral periphytonic taxa in general and members of the family Chydoridae in particular. The chydorids (78 \pm 35 and $77 \pm 27$ $\mathrm{n} / \mathrm{l})$ distinctly influence $(55.7 \pm 15.15 \%$ and $55.4 \pm 14.4 \%)$ abundance of Cladocera. This salient feature concurs with of the results of Sharma \& Sharma (2008) as well the observations in Loktak Lake (Sharma unpublished) while this generalization is in contrast to lack of any such pattern reported by several earlier workers (Khan 1987; Sanjer \& Sharma 1995; Sarma 2000; Sharma \& Hussain 2001; Khan 2003) from the Indian floodplain lakes. The Chydorids show significant density variations between months $\left(\mathrm{F}_{11,23}=20.929, \mathrm{P}<0.005\right)$ and insignificant between stations. They follow quantitative patterns concurrent with that of Cladocera and indicate relatively lower abundance between March-July. Abundance of the Chydoridae is negatively correlated with water temperature $\left(r_{1}=-0.637, r_{2}=-0.759\right)$ and rainfall $\left(r_{1}=-0.638\right.$, 
Table 2. Temporal variations of Microcrustacea of Deepor Beel

\begin{tabular}{|c|c|c|c|}
\hline & & Station I & Station II \\
\hline $\begin{array}{l}\text { QUALITATIVE } \\
\text { Microcrustaceans } \\
\text { Cladocera } \\
\text { Community similarity (\%) }\end{array}$ & $\begin{array}{l}51 \text { species } \\
45 \text { species }\end{array}$ & $\begin{array}{l}22-45(34 \pm 6) \\
17-41(29 \pm 6) \\
62.3-93.0\end{array}$ & $\begin{array}{l}25-46(38 \pm 6) \\
20-41(32 \pm 6) \\
63.8-98.9\end{array}$ \\
\hline $\begin{array}{l}\text { QUANTITATIVE } \\
\text { Zooplankton } \\
\text { Microcrustaceans } \\
\text { Percentage } \\
\text { Species Diversity } \\
\text { Dominance } \\
\text { Evenness }\end{array}$ & $\begin{array}{l}(\mathrm{n} / \mathrm{l}) \\
(\mathrm{n} / \mathrm{l})\end{array}$ & $\begin{array}{l}239-657(475 \pm 114) \\
120-305(216 \pm 53) \\
29.8-53.1 \quad(45.6 \pm 5.8) \\
2.223-3.336 \quad(2.975 \pm 0.310) \\
0.087-0.457 \quad(0.172 \pm 0.097) \\
0.712-0.931 \quad(0.845 \pm 0.056)\end{array}$ & $\begin{array}{l}255-687(459 \pm 128) \\
138-322(209 \pm 51) \\
43.9-58.6 \quad(50.8 \pm 4.5) \\
2.386-3.348(3.022 \pm 0.277) \\
0.098-0.435 \quad(0.185 \pm 0.084) \\
0.741-0.914 \quad(0.835 \pm 0.052)\end{array}$ \\
\hline $\begin{array}{l}\text { Different Groups } \\
\text { Cladocera } \\
\text { Percentage } \\
\text { Species Diversity } \\
\text { Dominance } \\
\text { Evenness } \\
\text { Copepoda } \\
\text { Percentage } \\
\text { Ostracoda } \\
\text { Conchostraca }\end{array}$ & $\begin{array}{l}(\mathrm{n} / \mathrm{l}) \\
(\mathrm{n} / \mathrm{l}) \\
(\mathrm{n} / \mathrm{l})\end{array}$ & $\begin{array}{l}43-252(142 \pm 59) \\
33.9-82.6(63.0 \pm 13.6) \\
2.525-3.141(2.885 \pm 0.259) \\
0.115-0.296(0.167 \pm 0.063) \\
0.769-0.962(0.864 \pm 0.068) \\
49-95(66 \pm 17) \\
16.4-59.1(32.8 \pm 11.9) \\
2-10(6 \pm 3) \\
0-4\end{array}$ & $\begin{array}{l}56-233(142 \pm 48) \\
40.6-72.4(60.5 \pm 9.1) \\
2.315-3.334(2.973 \pm 0.246) \\
0.089-0.303(0.170 \pm 0.062) \\
0.732-0.971(0.861 \pm 0.078) \\
66-101(81 \pm 13) \\
25.8-53.6(36.5 \pm 8.3) \\
2-10(5 \pm 2) \\
0-2\end{array}$ \\
\hline $\begin{array}{l}\text { Important Families (Clad } \\
\text { Chydoridae } \\
\text { Bosminidae } \\
\text { Daphniidae } \\
\text { Sidiidae }\end{array}$ & $\begin{array}{l}(\mathrm{n} / \mathrm{l}) \\
(\mathrm{n} / \mathrm{l}) \\
(\mathrm{n} / \mathrm{l}) \\
(\mathrm{n} / \mathrm{l})\end{array}$ & $\begin{array}{l}25-124(78 \pm 35) \\
6-59(23 \pm 20) \\
11-44(16 \pm 10) \\
2-35(13 \pm 10)\end{array}$ & $\begin{array}{l}25-111(77 \pm 27) \\
3-70(28 \pm 22) \\
5-51(19 \pm 12) \\
1-18(9 \pm 5)\end{array}$ \\
\hline $\begin{array}{l}\text { Important Cladocera spe } \\
\text { Chydorus sphaericus } \\
\text { Notalona karua } \\
\text { Bosmina longirostris } \\
\text { Bosminopsis deitersi }\end{array}$ & $\begin{array}{l}(\mathrm{n} / \mathrm{l}) \\
(\mathrm{n} / \mathrm{l}) \\
(\mathrm{n} / \mathrm{l}) \\
(\mathrm{n} / \mathrm{l})\end{array}$ & $\begin{array}{l}17 \pm 11 \\
13 \pm 7 \\
13 \pm 11 \\
10 \pm 9\end{array}$ & $\begin{array}{l}17 \pm 10 \\
9 \pm 11 \\
16 \pm 13 \\
12 \pm 10\end{array}$ \\
\hline $\begin{array}{l}\text { Important taxa (others) } \\
\text { Mesocyclops leuckarti } \\
\text { M. hyalinus } \\
\text { Nauplii }\end{array}$ & $\begin{array}{l}(\mathrm{n} / \mathrm{l}) \\
(\mathrm{n} / \mathrm{l}) \\
(\mathrm{n} / \mathrm{l})\end{array}$ & $\begin{array}{l}29 \pm 14 \\
11 \pm 6 \\
20 \pm 7\end{array}$ & $\begin{array}{l}33 \pm 13 \\
14 \pm 8 \\
28 \pm 13\end{array}$ \\
\hline
\end{tabular}

Table 3. Microcrustacea community similarities (Station I)

\begin{tabular}{|c|c|c|c|c|c|c|c|c|c|c|c|c|}
\hline & Nov & Dec & Jan & Feb & March & Apr & May & June & July & Aug & Sep & Oct \\
\hline Nov & - & 88.6 & 89.5 & 89.2 & 62.3 & 67.8 & 85.7 & 82.4 & 86.5 & 86.1 & 80.6 & 86.5 \\
\hline $\mathrm{Dec}$ & & - & 91.1 & 93.0 & 65.6 & 64.5 & 84.9 & 76.1 & 85.7 & 85.3 & 85.3 & 83.1 \\
\hline Jan & & & - & 89.2 & 65.7 & 64.4 & 80.0 & 82.4 & 78.4 & 83.3 & 80.6 & 81.1 \\
\hline Feb & & & & - & 64.7 & 63.6 & 80.5 & 80.0 & 83.9 & 81.0 & 83.5 & 86.4 \\
\hline March & & & & & - & 77.3 & 65.5 & 75.5 & 71.2 & 66.7 & 70.2 & 71.2 \\
\hline April & & & & & & - & 64.1 & 74.5 & 70.2 & 69.1 & 69.1 & 63.2 \\
\hline May & & & & & & & - & 67.7 & 82.3 & 90.9 & 81.8 & 82.3 \\
\hline June & & & & & & & & - & 72.7 & 75.0 & 75.0 & 78.8 \\
\hline July & & & & & & & & & - & 85.7 & 89.0 & 88.9 \\
\hline Aug & & & & & & & & & & - & 85.3 & 80.0 \\
\hline Sept & & & & & & & & & & & - & 80.0 \\
\hline Oct & & & & & & & & & & & & - \\
\hline
\end{tabular}

Table 4. Microcrustacea community similarities (Station I)

\begin{tabular}{|c|c|c|c|c|c|c|c|c|c|c|c|c|}
\hline & Nov & Dec & Jan & Feb & March & Apr & May & June & July & Aug & Sep & Oct \\
\hline Nov & - & 92.8 & 91.8 & 92.8 & 79.4 & 66.7 & 80.0 & 82.7 & 86.8 & 88.0 & 81.6 & 85.7 \\
\hline Dec & & - & 96.7 & 95.5 & 83.5 & 66.7 & 78.9 & 83.9 & 87.8 & 86.4 & 87.8 & 89.2 \\
\hline Jan & & & - & 98.9 & 82.5 & 65.7 & 80.5 & 87.8 & 86.7 & 85.4 & 86.7 & 88.1 \\
\hline Feb & & & & - & 81.0 & 63.8 & 78.9 & 88.9 & 85.4 & 83.9 & 85.4 & 89.2 \\
\hline March & & & & & - & 75.9 & 76.9 & 82.9 & 81.7 & 82.9 & 81.7 & 80.6 \\
\hline April & & & & & & - & 76.4 & 70.0 & 72.1 & 73.3 & 68.8 & 67.7 \\
\hline May & & & & & & & - & 80.6 & 79.4 & 83.6 & 79.4 & 78.3 \\
\hline June & & & & & & & & - & 82.2 & 83.3 & 82.2 & 81.1 \\
\hline July & & & & & & & & & - & 90.4 & 86.5 & 90.7 \\
\hline Aug & & & & & & & & & & - & 84.9 & 81.1 \\
\hline Sept & & & & & & & & & & & - & 88.0 \\
\hline Oct & & & & & & & & & & & & - \\
\hline
\end{tabular}


Rescaled Distance Cluster Combine

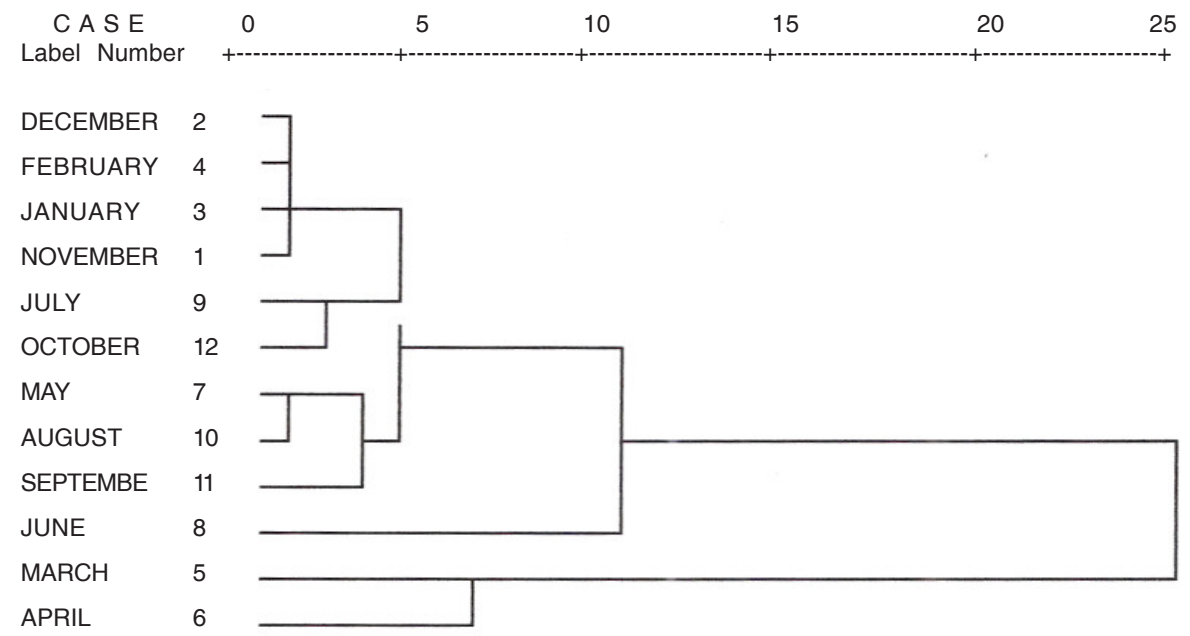

Rescaled Distance Cluster Combine
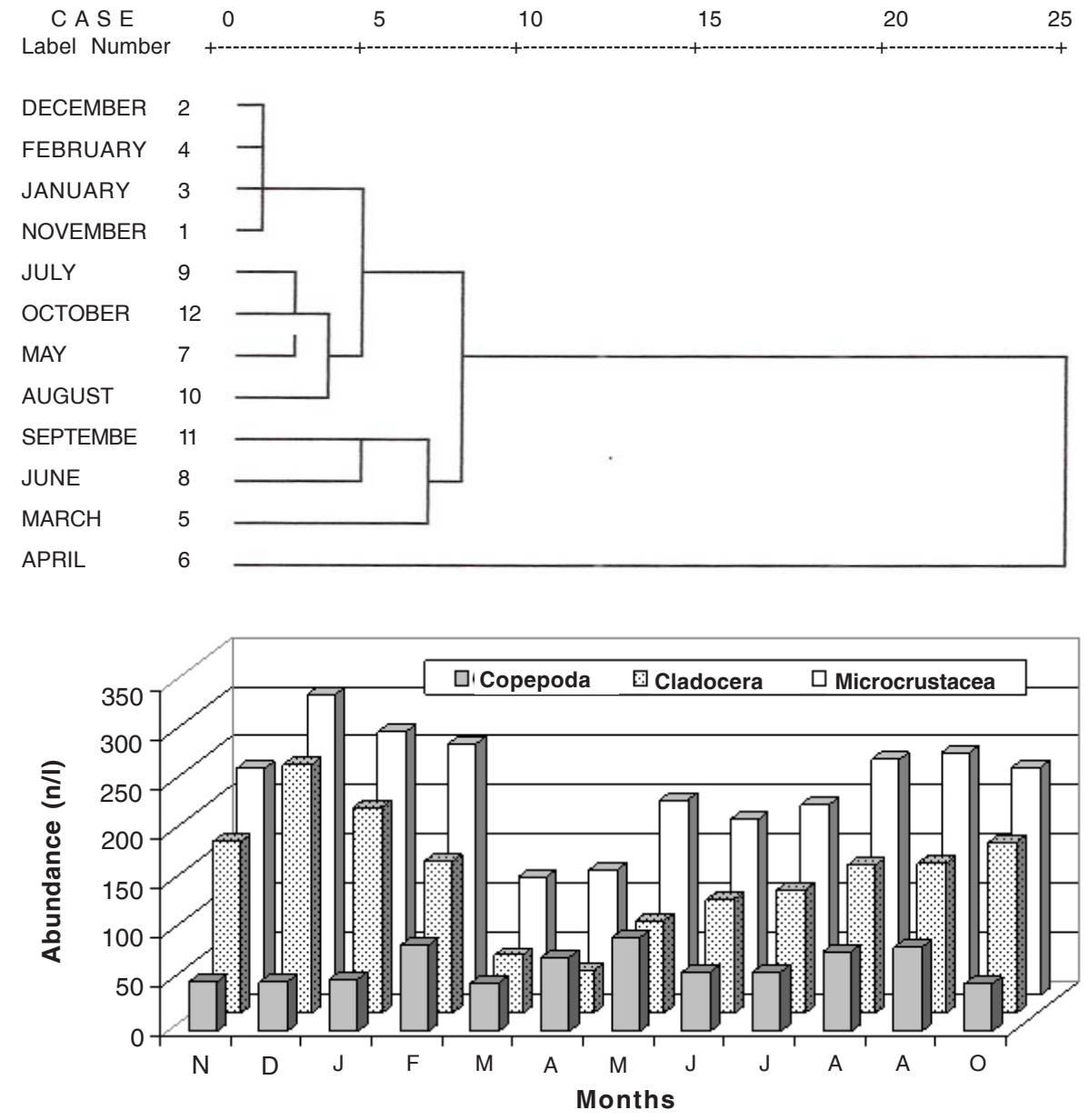

Figure 3. Hierarchical cluster analysis of Microcrustacea (Station I)

Figure 4. Hierarchical cluster analysis of Microcrustacea (Station II)

Figure 5. Monthly variations in abundance of Microcrustacea (Station I) 

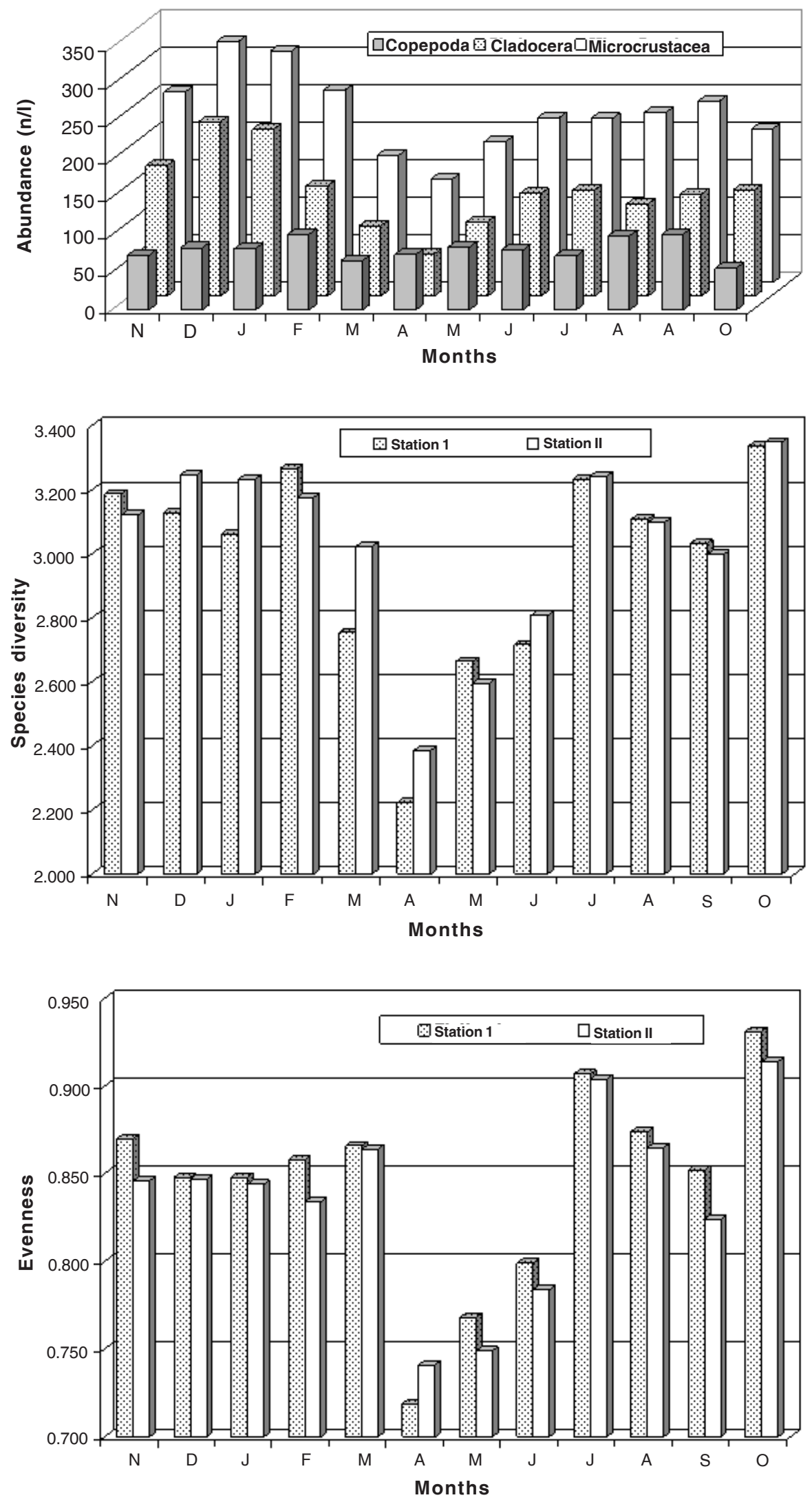

Figure 6. Monthly variations in abundance of Microcrustacea (Station II)

Figure 7. Monthly variations in species diversity of Microcrustacea

Figure 8. Monthly variations in evenness of Microcrustacea 


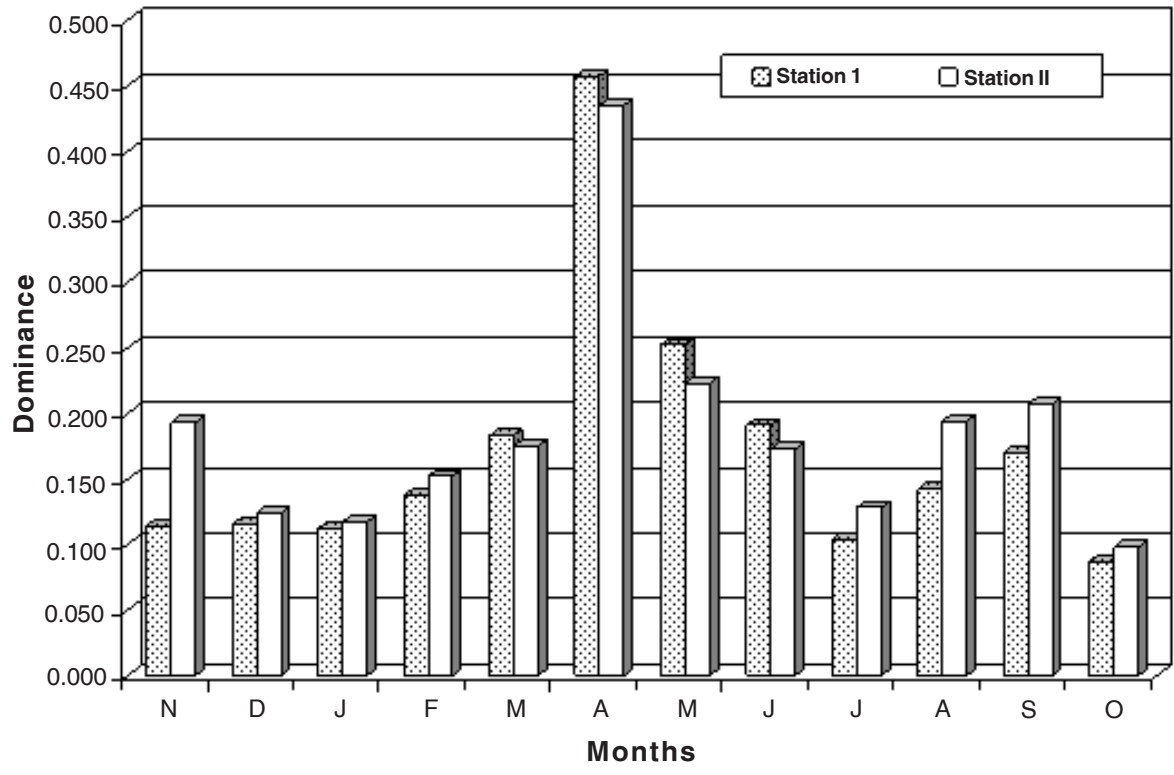

Figure 9. Monthly variations in dominance of Microcrustacea $\left.\mathrm{r}_{2}=-0.661\right)$, it is positively correlated with transparency $\left(\mathrm{r}_{1}=\right.$ $\left.0.605, r_{2}=0.673\right)$, dissolved oxygen $\left(r_{1}=0.652, r_{2}=0.777\right)$ and hardness $\left(r_{1}=0.548, r_{2}=0.609\right)$ at both stations and with specific conductivity $\left(r_{2}=0.615\right)$ and alkalinity $\left(r_{2}=0.640\right)$ at station II. Further, multiple regression indicates significantly higher cumulative effect of ten abiotic factors on their abundance $\left(\mathrm{R}^{2}{ }_{1}=0.921\right.$ and $\left.\mathrm{R}_{2}{ }_{2}=0.940\right)$ at both sampling stations.

Bosminidae $(23 \pm 20$ and $28 \pm 22 \mathrm{n} / \mathrm{l})>$ Daphniidae $(16 \pm 10$ and $19 \pm 12 \mathrm{n} / \mathrm{l}$ ) are sub-dominant families of Cladocera while Sidiidae $>$ Macrothricidae indicate limited importance. The Bosminidae register significant density variations between months $\left(\mathrm{F}_{11,23}=97.218, \mathrm{P}<0.005\right)$ as well as stations $\left(\mathrm{F}_{1,23}=\right.$ 15.129, $\mathrm{P}<0.005)$. They record relatively higher abundance between November-February and again between May-July and exhibit peaks during June at both sampling stations. Amongst the recorded abiotic factors, this family registers significant negative correlation only with $\mathrm{pH}\left(\mathrm{r}_{1}=-0.525, \mathrm{r}_{2}=-0.567\right)$ at both stations. On the other hand, the Daphniidae record importance during November-January with peaks during January and again between August-October; their winter peaks, mainly influenced by sporadic bloom of Daphnia lumholtzi, are supported by negative correlation with water temperature $\left(r_{1}\right.$ $\left.=-0.710, r_{2}=-0.813\right)$. This family registers significant quantitative variations between months $\left(\mathrm{F}_{11,23}=22.038, \mathrm{P}<\right.$ $0.005)$ and stations $\left(\mathrm{F}_{1,2 s}=5.949, \mathrm{P}<0.05\right)$. Amongst different species of Cladocera observed in this study, only a few namely Chydorus sphaericus, Notalona karua, Bosmina longirostris and Bosminopsis deitersi merit mention but no individual species is yet distinctly important quantitatively.

Copepoda (66 \pm 17 and $81 \pm 13 \mathrm{n} / \mathrm{l}$ ) form a sub-dominant group (Table 2) of Microcrustacea (32.8 \pm 11.9 and $36.56 \pm 8.3$ $\%)$ as well as of zooplankton (15.1 $\pm 6.5 \%$ and $18.7 \pm 4.9 \%)$ at two stations respectively. They follow (Figs. $5 \& 6$ ) trimodal and multimodal annual patterns with peaks during May (station I) and February and September (Station II) and minima during October (both stations) and indicate indefinite pattern of periodicity. They register significant quantitative variations between months $\left(\mathrm{F}_{11,23}=5.814, \mathrm{P}<0.001\right)$ and stations $\left(\mathrm{F}_{1,23}\right.$ $=17.998, \mathrm{P}<0.005)$. The sub-dominant nature of Copepoda is in contrast to their dominant role observed by Yadava et al. (1987), Baruah et al. (1993), Sharma \& Hussain (2001) and Khan (2003). Further, their abundance in Deepor beel is lower than the reports of Khan (1987), Sinha et al. (1994), Sharma \& Hussain (2001) and Khan (1987). Abiotic factors indicate limited influence on the copepod abundance as they register negative correlations with transparency $\left(r_{1}=-0.490\right)$ and hardness $\left(r_{1}=-0.552\right)$ at station I only. On the other hand, multiple regression indicates significantly higher cumulative effect of ten abiotic factors on their abundance $\left(\mathrm{R}^{2}{ }_{1}=0.999\right.$ and $\mathrm{R}_{2}^{2}=0.802$ ) at both sampling stations.

The cyclopoids mainly contribute to quantitative variations of Copepoda; their dominance concurs with the reports from the Indian floodplains by Khan (1987), Yadava et al. (1987), Sanjer \& Sharma (1995), Sarma (2000), Sharma \& Hussain (2001), and Khan (2003). Our results exhibit occurrence of nauplii throughout the study period; this feature reflects an active continuous reproductive phase of the cyclopoid copepods as also reported earlier by Yadava et al. (1987) and Sharma \& Hussain (2001). Ostracoda and Conchostraca, other groups of Microcrustacea, indicate poor abundance in this study.

The species diversity of Microcrustacea ranges between 2.223-3.336 and 2.386-3.348 at two sampling stations (Table 2) but registers higher mean values of $2.975 \pm 0.310$ and $3.022 \pm 0.277$ respectively. The stated ranges are rather misleading as monthly diversity values less than 3.0 are observed only during March-June (station I) and April-June (station II). The species diversity follows multimodal and trimodal annual patterns at two stations (Fig. 7) and registers significant temporal variations between months $\left(\mathrm{F}_{11,23}=28.240\right.$, $\mathrm{P}<0.005)$ only. It indicates peaks during October and minima during summer (April) at both stations. Further, it registers significant positive correlations with richness of Microcrustacea $\left(r_{1}=0.833, r_{2}=0.797\right)$ and Cladocera $\left(r_{1}=0.803, r_{2}=0.810\right)$ as well as with abundance of Microcrustacea $\left(r_{1}=0.714, r_{2}=\right.$ $0.659)$ and Cladocera $\left(r_{1}=0.736, r_{2}=0.712\right)$ at both sampling stations.

Our results show (Table 2 ) higher microcrustacean evenness (0.845 \pm 0.056 and $0.835 \pm 0.052)$ which depicts marginal differences in mean values at two stations and 
registers significant temporal variations between months $\left(\mathrm{F}_{11}\right.$ $\left.{ }_{23}=74.278, \mathrm{P}<0.005\right)$ as well as stations $\left(\mathrm{F}_{1,23}=6.634, \mathrm{P}<\right.$ 0.02). In general, higher evenness affirms equitable abundance of various species. It follows (Fig. 8) multimodal but different annual patterns with peaks during October and April, records minima during April and December at the two sampling stations respectively and exhibits relatively lower values between April-June at both stations. Evenness of Microcrustacea is positively correlated with their species diversity $\left(r_{1}=0.633, r_{2}=0.912\right)$. Besides, it is positively correlated with richness of Cladocera $\left(r_{2}=0.504\right)$ at station II.

Microcrustacea exhibit (Table 2 ) lower dominance $(0.172 \pm 0.097$ and $0.185 \pm 0.084)$, hence, our results affirm lack of quantitative importance of individual species. Dominance indicates relatively higher values during March-June and again during September at two sampling stations. It registers significant monthly variations $\left(\mathrm{F}_{11,23}=34.713, \mathrm{P}<0.005\right)$ only, follows (Fig. 9) broadly bimodal and trimodal annual patterns at two sampling stations and records peaks during April and minima during October each at both stations. Dominance is negatively correlated with species diversity $\left(r_{1}\right.$ $-0.930)$ and evenness $\left(r_{1=}-0.591\right)$, richness $\left(r_{1}=-0.718\right)$ and abundance $\left(r_{1=}-0.643\right)$ of Microcrustacea $)$ as well as with richness $\left(r_{1=}-0.706\right)$ and abundance $\left(r_{1=}-0.723\right)$ of Cladocera at station I only while no such correlations are evident at station II.

The present results are also characterized (Table 2 ) by

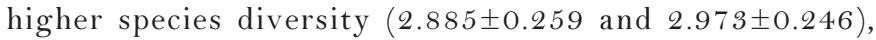
higher evenness $(0.864 \pm 0.068$ and $0.861 \pm 0.078)$ and lower dominance (0.167 \pm 0.063 and $0.170 \pm 0.062)$ of Cladocera. These salient features concur with the results of Sharma \& Sharma 2008). Further, all three parameters register insignificant variations between months as well as stations. Higher evenness and lower dominance of Cladocera affirm lower densities and equitable abundance of majority of species of this important qualitative and quantitative group of Microcrustacea.

To sum up, Microcrustacea of Deepor Beel exhibit diverse and speciose character as well as the richest faunal diversity recorded from any individual freshwater ecosystem inIndia. Our results indicate lack of definite periodicity of richness or abundance of the microcrustaceans or their constituent groups. The present results are characterized by higher species diversity, higher evenness and lower dominance of both Microcrustacea as well as Cladocera, and indicate lower densities of majority of species and lack of distinct quantitative importance of any individual species. Water temperature, rainfall, specific conductivity and dissolved oxygen record significant influence on richness and abundance, other factors show limited importance but multiple regression registers significant cumulative influence of ten abiotic factors on the stated parameters.

\section{References}

APHA (1992). Standard Methods for the Examination of Water and Wastewater $\left(18^{\text {th }}\right.$ ed.). American Public Health Association, Washington D.C., 1198 pp.

Baruah, A., A.K. Sinha \& U.P. Sharma (1993). Plankton variability of a tropical wetland, Kawar (Begusarai), Bihar. Journal of Freshwater Biology 5: 27-32.

Fernando, C.H. \& A. Kanduru (1984). Some remarks on the latitudinal distribution of Cladocera on the Indian subcontinent. Hydrobiologia 113: 69-76.

Khan, M.A. (1987). Observations on Zooplankton composition, abundance and periodicity in two flood plain lakes of the Kashmir Himalayan valley Acta Hydrochemica Hydrobiologia 15: 167-174.

Khan, R.A. (2003). Faunal diversity of zooplankton in freshwater wetlands of Southeastern West Bengal. Records of the Zoological Survey of India, Occasional Paper No. 204: 1-107.

Korovchinsky, N.M. (1992). Sididae and Holopedidae. In: Guides to the Identification of the Microinvertebrates of the Continental Waters of the World. Vol. 3. SPB Academic Publishers. The Hague, 82pp.

Ludwig, J.A. \& J.F. Reynolds (1988). Statistical ecology: a primer on methods and computing. John Wiley \& Sons, New York, 337pp.

Magurran, A.E. (1988). Ecological Diversity and its Measurement. Croom Helm Limited, London, 179pp.

Michael, R.G. \& B.K. Sharma (1988). Indian Cladocera (Crustacea: Branchiopoda: Cladocera). Fauna of India and adjacent countries Series. Zoological Survey of India, Calcutta.

Orlova-Bienkowskaja, M.Y. (2001). Cladocera: Anomopoda. Daphniidae: genus Simocephalus. In: Guides to the Identification of the Microinvertebrates of the Continental Waters of the World. Vol. 17. Backhuys Publishers, Leiden, the Netherlands, 130pp.

Sarma, P.K. (2000). Systematics, distribution and ecology of zooplankton of some floodplain wetlands of Assam, India. Ph.D Thesis, Gauhati University, Assam.

Sanjer, L.R. \& U.P. Sharma (1995). Community structure of plankton in Kawar lake wetland, Begusarai, Bihar: II Zooplankton. Journal of Freshwater Biology 7: 165167.

Sharma, B.K. \& M. Hussain (2001). Abundance and Ecology of Zooplankton in a tropical floodplain lake, Assam (N.E. India). Ecology, Environment \& Conservation 7(4): 397-403.

Sharma, B.K. \& R.G. Michael (1987). Review of taxonomic studies on freshwater Cladocera from India with remarks on biogeography. Hydrobiologia 145: 29-33.

Sharma, B.K. \& S. Sharma (1999). Freshwater Cladocerans (Crustacea: Branchiopoda: Cladocera). In: Fauna of Meghalaya; State Fauna Series 4. (9): 469-550. Published by Zoological Survey of India, Calcutta.

Sharma, B.K. \& S. Sharma (2008). Faunal diversity of Cladocera (Crustacea: Branchiopoda) of Deepor beel, Assam (Northeast India) - A Ramsar site. Journal of the Bombay Natural History Society 105(2): 196-201.

Sharma, S. \& B.K. Sharma (2008). Zooplankton diversity in floodplain lakes of Assam. Records of the Zoological Survey of India, Occasional Paper No. 290: 1-307.

Sinha, A.K., A. Baruah, D.K. Singh \& U.P. Sharma (1994). Biodiversity and pollution status in relation to physico-chemical factors of Kawar lake (Begusarai), North Bihar. Journal of Freshwater Biology 6: 309331.

Smirnov, N.N. (1971). The World Chydorid Fauna (in Russian). USSR Academy of Science Zoological Institute Nova series 101, Leningrad, $539 \mathrm{pp}$.

Smirnov, N.N. (1976). The World Macrothricidae (in Russian). USSR Academy of Science Zoological Institute Nova series 104, Leningrad, $112 \mathrm{pp}$.

Smirnov, N.N. (1992). The Macrothricidae of the world. In: Guides to the identification of the Microinvertebrates of the Continental waters of the World. Vol. 1. SPB Academic Publishers, The Hague, 143pp.

Smirnov, N.N. (1996). Cladocera: the Chydorinae and Sayciinae (Chydoridae) of the world. In: Guides to the identification of the Microinvertebrates of the Continental waters of the World. Vol. 11. SPB Academic Publishers, The Hague, 197pp.

Talling. J.F. \& I.B. Talling (1965). The chemical composition of African lake waters. Internationale Revue gesammten Hydrobiologie 50: 421463.

Yadava, Y.S., R.K. Singh, M. Choudhury \& V. Kolekar (1987). Limnology and productivity in Dighali beel (Assam). Tropical Ecology 28: $137-146$.

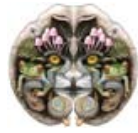

